\title{
Critical Appreciation of Power System in Bangladesh
}

\author{
M. A. Haque, *a J. Azad ${ }^{b}$ and J. Rahman ${ }^{b}$ \\ ${ }^{a}$ Department of Physics, University of Chittagong, Chittagong and ${ }^{b}$ Department of Applied Physics, Electronics \\ and Communication Engineering, University of Dhaka, Bangladesh
}

\begin{abstract}
The overall civilization of a nation depends on electricity. This is essential for a more stable and livable world, particularly in this age of globalization, information and communication technology. In Bangladesh power system is interconnection of power generation, transmission and distribution. Due to interconnection, the power system becomes large and complex. Shortage of power is a serious problem and strong barrier for the development of our country. Development of power sector indicates the enhancing power generation, reducing system loss and ensures proper distribution among the consumers. In this paper it has been analyzed the main problems and a proposal has been proposed for overcoming those problems that will help to development the power system.
\end{abstract}

Key words: Compact Florescent Lamp (CFL), Independent power producers (IPP), Underground transmission line, Proper load management, Transformers and switchgear, Misuse and corruption and system loss.

\section{Introduction}

Energy exists in different forms in nature. The sources of energies are sun, wind, water, coal, fossils, oil and gas. Electrical power is the conversion of these resources. Electricity is the most convenient form of energy. It is clean, easy to transport and be converted to other forms of energy and is available with a click of switch. So, it has kept its place as the main source of energy in residential, commercial and industrial applications. Electrical energy plays a vital role in development of civilization. Sufficient and reliable source of electricity is a major prerequisite for a sustained and successful economic development effort and poverty reduction (IUT, 2008). Power system is the combination of three terms generation, transmission and distribution. In Bangladesh power stations generate electricity then it is transmitted by Power Grid Company of Bangladesh Ltd. (PGCB) to distribution substations and then consumers are getting electricity from those substations (www.pgcb. gov.bd). Due to interconnection, the power system becomes large and complex.

Shortage of power is a serious problem and strong barrier for the development of our country. Government (GOV) has made vision and policy regarding power sector improvement. Improvement of power sector indicates the increasing power generation, reducing system loss and ensures proper distribution among the consumers. For that vision GOV has given top priority to develop the power sector considering its importance in overall development of the country. The GOV has set the goal of providing electricity to all citizens by 2020 (MPEMR, 2009). The main problems of existing power system in Bangladesh are generation of electric power is not sufficient to meet the demand, moreover the demand is increasing day by day; transmission loss plays a great role in power crisis and corruption, irresponsibility \& shortage of modern technology are the main obligations regarding distribution. The purpose of this paper is to analyze the main problems and a proposal has been proposed for overcoming those problems that will help to development the power system in Bangladesh.

\section{Present status of power system in Bangladesh}

Regarding power sector different utilities are working under the guidance of Power Division, Ministry of Power, Energy \& Mineral Resources (MPEMR). A single line phase diagram of a power system (generation, transmission and distribution.) is shown in Fig. 1:

\footnotetext{
* Corresponding author: asad2310@gmail.com
} 


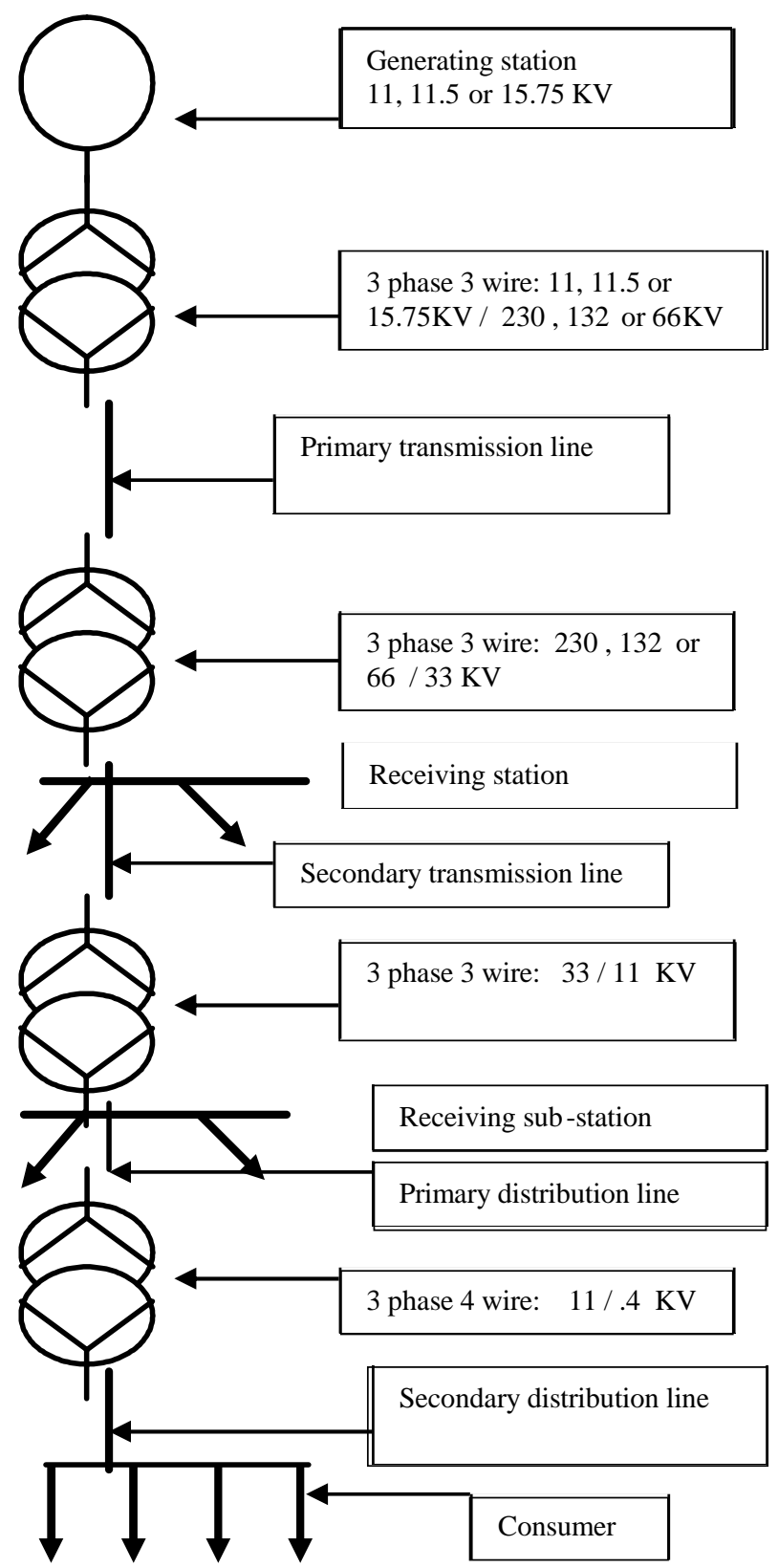

Fig. 1. Single line diagram of power system

\section{Overview of power generation in Bangladesh}

Power generation is the most important part of the power system. Bangladesh Power Development Board (BPDB), Independent Power Producers (IPPs) and Electricity Generation Company of Bangladesh Ltd. (EGCB) generates power in Bangladesh. Different types of power plants generate electricity and synchronize it with the national grid.
There are some isolated diesel power stations at remote places and islands which are not connected with the national grid. At present, BPDB operates 30 power stations (Including IPP) with a total installed capacity of $5466 \mathrm{MW}$. The information about power stations are shown in Table I: (MPEMR, 2008) 
Table I. Information about power stations in Bangladesh

\begin{tabular}{|c|c|c|c|c|c|c|}
\hline \multicolumn{7}{|c|}{ Public Sector } \\
\hline $\begin{array}{l}\text { S. } \\
\text { No }\end{array}$ & Power Station & $\begin{array}{c}\text { No of } \\
\text { units }\end{array}$ & Types of units & Type of fuel & \begin{tabular}{|l} 
Installed \\
Capacity MW
\end{tabular} & $\begin{array}{c}\text { Generation } \\
\text { capacity MW }\end{array}$ \\
\hline 1 & Karnafuli & 5 & Hydro & Hydro & 230 & 230 \\
\hline 2 & $\begin{array}{l}\text { Ashuganj } \\
\text { Combined Cycle } 3\end{array}$ & 8 & Steam Turbine 5 & Gas & 744 & 610 \\
\hline 3 & Siddhirganj & 2 & Steam Turbine & Gas & 260 & 245 \\
\hline 4 & Haripur & 3 & Combustion Turbine & Gas & 99 & 90 \\
\hline 5 & Tongi & 1 & Combustion Turbine & Gas & 105 & 105 \\
\hline 6 & Ghorasal & 6 & Steam Turbine & Gas & 950 & 820 \\
\hline 7 & Shahjibazar & 6 & Combustion Turbine & Gas & 166 & 80 \\
\hline 8 & Fenchuganj & 3 & Combined Cycle & Gas & 90 & 90 \\
\hline 9 & Sylhet & 1 & Combustion Turbine & Gas & 20 & 20 \\
\hline 10 & Raozan & 2 & Steam Turbine & Gas & 420 & 360 \\
\hline 11 & $\begin{array}{l}\text { Sikalbaha } \\
\text { Combustion Turbine } 1\end{array}$ & 2 & Steam Turbine 1 & Gas & 116 & 62 \\
\hline 12 & $\begin{array}{l}\text { Khulna } \\
\text { Combustion Turbine } 2\end{array}$ & 4 & Steam Turbine 2 & F.Oil & 226 & 168 \\
\hline 13 & Bheramara & 3 & Combustion Turbine & High speed Diesel & 60 & 56 \\
\hline 14 & Saidpur & 1 & Combustion Turbine & High speed Diesel & 20 & 20 \\
\hline 15 & Thakurgaon & 3 & Diesel & Light diesel oil & 4.5 & 2 \\
\hline 16 & Barishal & 5 & $\begin{array}{l}\text { Diesel } 3 \\
\text { Combustion Turbine } 2\end{array}$ & High speed Diesel & 47.14 & 37 \\
\hline 17 & Rangpur & 1 & Combustion Turbine & High speed Diesel & 20 & 19 \\
\hline 18 & Bhola & 6 & Diesel & $\begin{array}{l}\text { F. Oil } 1 \\
\text { High speed Diesel } 2\end{array}$ & 6.76 & 4.6 \\
\hline 19 & Baghabari & 2 & Combustion Turbine & Gas & 171 & 171 \\
\hline 20 & Barapukuria & 2 & Steam Turbine & Coal & 250 & 205 \\
\hline 21 & Rooppur & 15 & Nuclear & Nuclear fuel & 600 & Proposed \\
\hline \multicolumn{7}{|c|}{ Private Sector } \\
\hline 1 & NEPC Haripur (BMPP) & 8 & Diesel & Gas & 110 & 110 \\
\hline 2 & RPC (Mymenshingha) & 4 & $\begin{array}{l}\text { Combustion } \\
\text { Turbine }\end{array}$ & Gas & 140 & 140 \\
\hline 3 & CDC Haripur & 1 & Combustion Turbine & Gas & 360 & 360 \\
\hline 4 & CDC Meghnaghat & 3 & Combustion Turbine & Gas & 450 & 450 \\
\hline 5 & KPCL (BMPP) & 18 & Diesel & F. Oil & 110 & 110 \\
\hline \multirow[t]{2}{*}{6} & Baghabari BMPP & & & & & \\
\hline & West Mont (WPL) & 2 & Combustion Turbine & Gas & 90 & 88 \\
\hline 7 & Khulna Barge-mounted & 2 & Combustion Turbine & oil & 56 & 40 \\
\hline 8 & Sikhalbaha Barge-mounted & 2 & Combustion Turbine & oil & 56 & 40 \\
\hline
\end{tabular}


Table II. Installed capacity of power stations

\begin{tabular}{l|c|c|c}
\hline \multicolumn{2}{c|}{ By type of plant } & \multicolumn{2}{c}{ By type of fuel } \\
\hline Hydro & 230 MW (4.39\%) & Gas & $4000 \mathrm{MW}(81.43 \%)$ \\
Steam turbine & $2,435 \mathrm{MW}(51.25 \%)$ & Furnace oil & $294.75 \mathrm{MW}(5.34 \%)$ \\
Gas turbine & $1009 \mathrm{MW}(20.95 \%)$ & Diesel & $204.25 \mathrm{MW}(4.08 \%)$ \\
Combined cycle & $990 \mathrm{MW}(18.88 \%)$ & Hydro & $230 \mathrm{MW}(4.39 \%)$ \\
Diesel & $238 \mathrm{MW}(4.54 \%)$ & Coal & $216 \mathrm{MW}(4.77 \%)$ \\
\hline Total: & $4800 \mathrm{MW}(100 \%)$ & Total: & $4800 \mathrm{MW}(100 \%)$ \\
\hline
\end{tabular}

The installed capacity of power station including IPP is shown in table 2: (Pub. Of spilling energy, 2008)

\section{Transmission system in Bangladesh}

Only Power Grid Company of Bangladesh Ltd. (PGCB) transmits power from power station to sub-station. Classification of transmission system is shown in the diagram 1:

\section{Perspective of distribution system}

A distribution system connects all loads in a particular area to the transmission system. Classifications of distribution system in Bangladesh are shown in diagram 2:

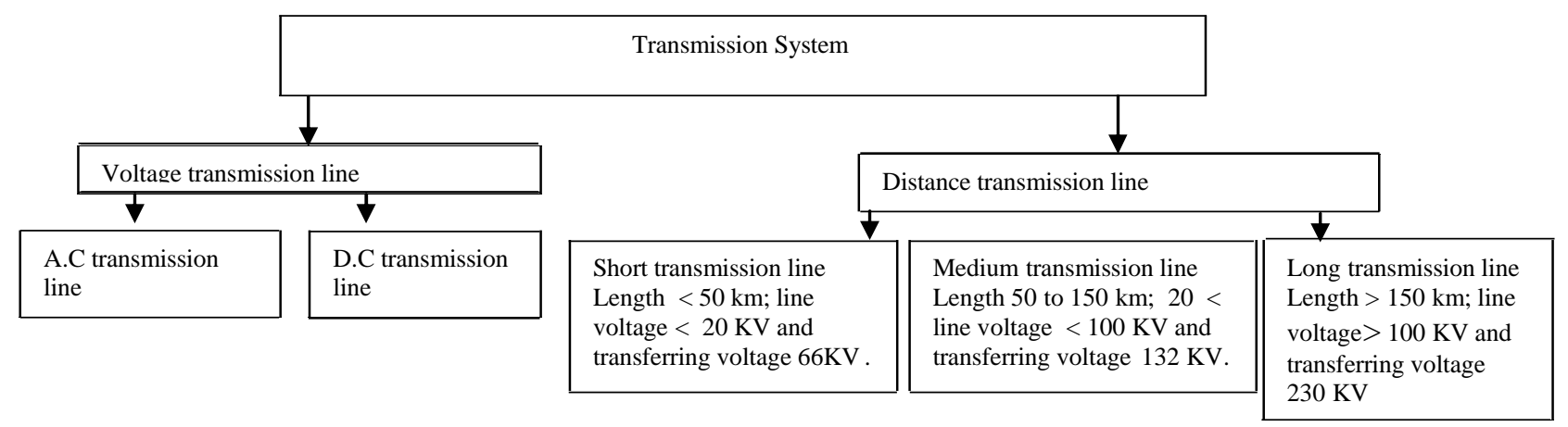

Diagram 1: Classification of transmission system

Table III. Operational performance of transmitted electricity of PGCB

\begin{tabular}{l|c|c|c|c|c|c}
\hline Fiscal Year & $\begin{array}{c}\text { Net electricity } \\
\text { generation } \\
\text { (Million kWh) }\end{array}$ & $\begin{array}{c}\text { Net electricity } \\
\text { transmitted } \\
\text { (Million kWh) }\end{array}$ & Transmission loss \% & \multicolumn{3}{|c}{ Length in route-kilometers } \\
\cline { 3 - 6 } $2003-04$ & 20062 & 19327 & 3.48 & 683 & 2,658 \\
$2004-05$ & 21162 & 20439 & 3.42 & 734 & 2760 \\
$2005-06$ & 22738 & 21955 & 3.44 & 734 & 2932 \\
$2006-07$ & 22771 & 22053 & 3.15 & 734 & 2932 \\
$2007-08$ & 24296 & 23435 & 3.55 & 734 & 3018 \\
\hline
\end{tabular}

Operational performance of transmitted electricity and transmission line length of PGCB is shown in Table III: (IUT, 2008, www.pgcb.gov.bd ) 


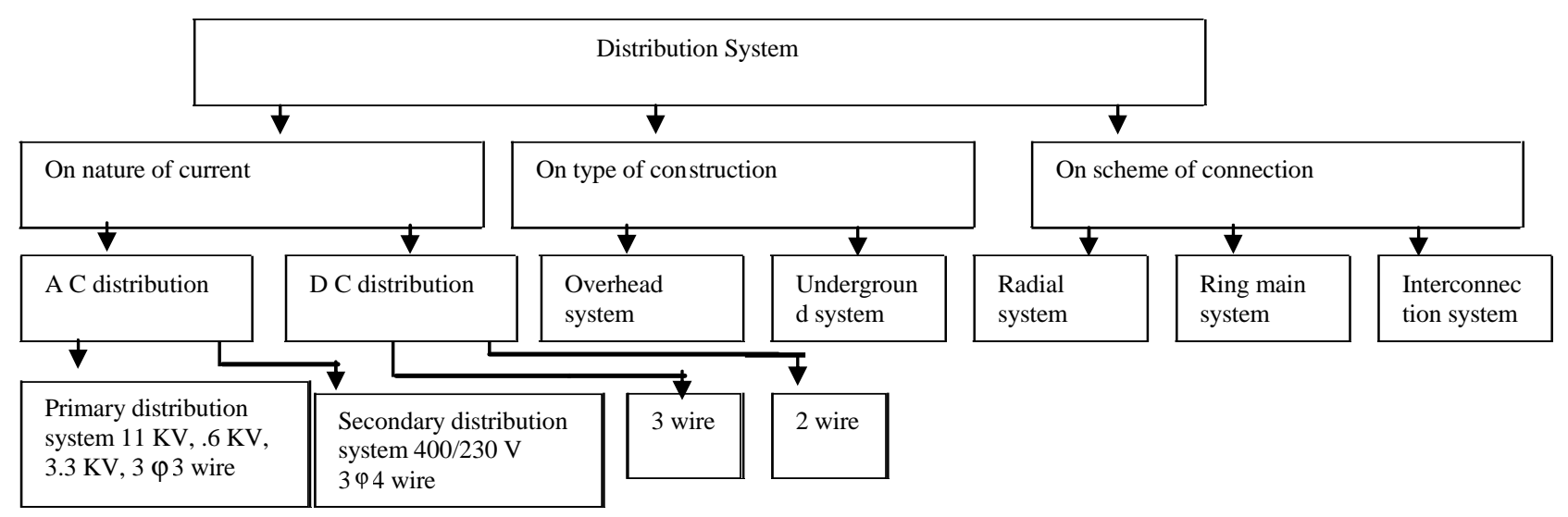

Diagram 2: Classifications of distribution system in Bangladesh

In Bangladesh the following agencies distributes electricity among the consumers: Bangladesh Power Development Board (BPDB), Dhaka Electric Supply Company Ltd. (DESCO), Dhaka Power Division Company Ltd. (DPDC), Rural Electrification Board (REB) through rural electric Cooperatives called Palli Bidyut Samati (PBSs) and West Zone Power Distribution Company Ltd. (WZPDC).

Besides that North Zone Power Distribution Company Ltd. (NZPDC), South Zone Power Distribution (SZPDC) and Central Zone Power Distribution Company Ltd. (CZPDC) are in formation stage.

For the development of distribution system in the urban areas, BPDB takes different Town Distribution Projects (TDP) and Rural Electrification Board (REB) develops distribution system in the rural areas through different rural Electrification Program. The distribution system expanded dramatically. In 1972 there was only $9010 \mathrm{~km}$ of distribution lines and total consumer was over 250000 where in December 2008 the total distribution line is $271000 \mathrm{~km}$ and consumer number 10.3 million (Kazi Awal, 2008). Consumption pattern of BPDB is shown in Table IV: ( IUT, 2008)

Table IV. Consumption pattern of BPDB

\begin{tabular}{l|c}
\hline Name of the sector & Amount \\
\hline REB & $38.48 \%$ \\
DPDC & $25.26 \%$ \\
DESCO & $9.69 \%$ \\
Domestic & $8.50 \%$ \\
WZPDCL & $6.55 \%$ \\
Large industry and commercial & $5.89 \%$ \\
Small commercial & $2.15 \%$ \\
Small industrial & $1.74 \%$ \\
Agriculture & $0.38 \%$ \\
Others & $1.27 \%$ \\
\hline
\end{tabular}

\section{Inconvenience of power system in Bangladesh:}

\section{Problems in generation sector}

Present generation, demand and crisis of power in Bangladesh (December, 2008) is shown in Table V: (Pub. Of spilling energy, 2008)

Table V. Data on power crisis in Bangladesh

\begin{tabular}{l|c|c|r|c}
\hline Year & $\begin{array}{c}\text { Installed } \\
\text { capacity } \\
\text { (MW) }\end{array}$ & $\begin{array}{c}\text { Generation } \\
\text { capability } \\
\text { (MW) }\end{array}$ & $\begin{array}{c}\text { Demand } \\
\text { forecast } \\
\text { (MW) }\end{array}$ & $\begin{array}{c}\text { Load } \\
\text { shedding } \\
\text { (MW) }\end{array}$ \\
\hline $2003-04$ & 4680 & 3592 & 4259 & 694 \\
$2004-05$ & 4685 & 3782 & 4375 & 800 \\
$2005-06$ & 4690 & 3810 & 4490 & 1312 \\
$2006-07$ & 4693 & 3849 & 4550 & 1212 \\
$2007-08$ & 5466 & 4415 & 4800 & 385 \\
\hline
\end{tabular}

Generation of electric power in Bangladesh is not sufficient to meet the demand. Moreover the demand is increasing day by day. Presently in power system total installed generation capacity is $5466 \mathrm{MW}$ (public 3848MW, private $1618 \mathrm{MW}$ ) where as maximum available generation is 4415 MW to supply the demand $4800 \mathrm{MW}$. Load shedding in the country on February 2009 is 600 MW (www. bpdp.gov.bd). The main constraints in power generation are:

1. Most of the power stations have lost their lifetime; due to shortage of proper maintenance \& replacement of existing parts \& components of the stations they are not reliable for steady generation.

2. Most of the power stations have lost their lifetime; due to shortage of proper maintenance \& replacement of 
existing parts \& components of the stations they are not reliable for steady generation.

3. Alarming signal for the power sector in Bangladesh is the dependence of the coal/gas which may turn out. In that case our power sector will be collapsed and the nation will go back to dark from civilization.

4. Power doesn't transfer properly due to the long distance between power station and distribution sub-station.

5. During winter season due to the crisis of water some of the units of hydro station are in tripped.

6. Due to the lack of huge fund it is not possible to set up nuclear power plant to meet the demand. On the other hand, already 50 years have crossed after pilot project at Rooppur from where no outputs come yet.

7. Though GOV has taken steps to encourage IPP to generate power but due to high price consumers are not showing interest to use anything from private sector.

8. In this modern era most of the countries are using renewable energy for power generation but in our country it is not spreading out due to the shortage of skilled manpower, modern technology and people awareness.

9. There is no reliable protective system in power generation sector. So when any unit or plants are collapsed it will hamper the national grid. For example, $360 \mathrm{MW}$ IPP Haripur tripped on 06. 02. 09 that directly hampers the national grid.

\section{Constraints in transmission system}

Transmission loss plays a great role in power system. Several types of losses are induced in transmission line. The main reason for transmission losses are:

1. In the transmission line one time voltage has been stepup from 11/11.5/15.75 KV to 230/132/66 KV then step down $230 \mathrm{KV}$ to $132 \mathrm{KV}$ and then $132 \mathrm{KV}$ to $66 \mathrm{KV}$ to the substation by using transformer and switchgear. During the compulsion of following steps fluctuation of frequency can't controlled properly and the voltage is reduced. Moreover the distance between station and sub-station is maximum in Bangladesh in comparison to other countries. Hence, In that case transformer and switchgear working under more pressure. For that reason depreciation is increased in transformer and switchgear.

2. Electric cables are made up of copper. Copper loss is one of the reasons of transmission line loss. In transmission line the resistance of the conductor will never be zero. When current flows through the conducting cables, some energy is dissipated in the form of heat that leads to power loss. Skin effect is also the reason of copper loss.

3. Dielectric losses indicate the heating effect on the dielectric materials between the conductors.

4. Induction losses occur when electromagnetic field about a conductor cuts through any nearby metallic object and current is induced in that object. When some magnetic lines of force about a conductor don't return to the conductor during cycle alternates then the radiation losses occurred.

5. The transmission line in Bangladesh is overheaded that takes mechanical support to set up line which is cost effective and it doesn't support the high voltage to transfer. During thunderstorm when the support damaged then cables are disconnected and accident occurs. It takes more distance and other components then underground transmission line.

6. Development of transmission sector could not possible due to the lack of sufficient fund. There is a lack of security and contingencies for different elements in transmission investment.

7. Generation transmission mismatches due to deviation of planning, lack of fund and delay in project implementations.

8. Dependence of foreign countries for equipments, construction materials and spare parts. Lack of experienced construction firms.

9. Lack of qualified and skilled manpower because they are going abroad on higher salaries and also getting better job in other sectors in the country.

10. During construction and operation challenges areVoltage division in different level of the system, regional unbalance between generation \& demand, theft of transmission tower member and threat to river crossing towers due to change of course of rivers. 
11. Corruption, dishonesty and lack of responsibility of the employers are also the reason for transmission loss.

\section{Present crisis in power distribution sector}

The objective of distribution system is to assure that the growing demand for electricity in terms of increasing growth rate and high load density can be satisfied in an optimum way. In Bangladesh up to December 2008, only the distribution system loss is $16.52 \%$ (IUT, 2008). The following factors are responsible for the loss of distribution system:

1. Corrupt management, consumption loss, billing loss, collections loss and defective meters are the major loss perspective of distribution system.

2. Unplanned and non-standard service connection, old distribution facilities are available in power sector which is not adjustable in these modern technological eras.

3. In our power sector distribution lines are long which increase the system loss.

4. Lack of adequate reactive power compensation.

5. Consumers are using more loads than sanctioned that effect on lines and transformer.

\section{Steps taken for enhancing power sector in Bangladesh}

For solving the power crisis Government has taken the following steps:

1. Under Renewable Energy Program the following projects are on going such as solar energy project, biomass based power plant project and wind energy project for increment of power generation.

The government proposed a project Rooppur Nuclear Power Plant (RNPP) of installed capacity $600 \mathrm{MW}$ in 1961. Bangladesh Atomic Energy Commission (BAEC) has been set up Atomic Energy Research Establishment (AERE) at Savar in 1986 of installed capacity 20 MW that is used only research purpose. BAEC has trained up a good number of professionals in various branches of nuclear technology to be involved in different implementation of phases of RNPP.

Besides that GOV encourages industries to install their own small electricity generating plants so that they can continue uninterrupted production during the load shedding. Private power companies are also allowed to produce and supply power to the national grid under agreed terms. Barge-mounted plants are the result of first such initiatives by the private sector. The private sector power plants that have recently started production include those at Baghabari (110 MW), Haripur (110 MW and 360 MW), Khulna (110 MW), Mymensingh (60 MW) and Meghnaghat (450 MW) all under the IPP (EEE, IUT, 2008).

\section{Future development plan}

GOV has made vision and policy regarding power sector improvement. For that vision it is mentioned that providing access to affordable and reliable electricity to the majority of the people of Bangladesh by 2020 is a national goal of the next millennium. For that purpose GOV issued its vision and policy on power sector reforms with the following objectives:

1. Bringing the entire country under electricity service by the year 2020 in phases.

2. Making the power sector financially viable and able to facilitate economic growth.

3. Introducing new corporate culture in the power sector entities and increasing the sector's efficiency.

5. Improving the reliability and quality of electricity supply.

6. Ensuring reasonable and affordable price for electricity by pursuing least cost options.

Table V. Power system development plan up to 2020

\begin{tabular}{l|c|c|c}
\hline Items & 2005-2008 & 2008-2012 & 2013-2020 \\
\hline Installed capacity (MW) & 6441 & 9666 & 17765 \\
Peak demand (MW) & 5368 & 7887 & 14600 \\
Transmission line (km) & 4898 & 7180 & 8396 \\
Distribution line (km) & 266375 & 345560 & 477558 \\
No. of consumers million & 9.03 & 12.75 & 20.76 \\
\hline
\end{tabular}

Power system development plan up to 2020 is shown in Table V (Khizir Khan, 2007)

GOV is currently working with an interim target of providing electricity to $60 \%$ of the population by 2010 . GOV has taken Power System Master Plan (PSMP) and Millennium Development Goals (MDGs) to fulfill that interim target. 


\section{Proposal for the development of power system in Bangladesh}

Development of power system indicates the increasing power generation, reduction of system loss and ensured proper distribution. System losses play the major role in case of power crisis in Bangladesh. At least $25 \%$ of total demand could be full-filled by reducing system loss.

\section{Increasing power generation}

The following steps should be taken for increasing the power generation:

\section{Encourage Independent Power Producers (IPP)}

The GOV should encourage owner of industry or factory to install their own small electricity generating plants. For this, GOV should help them to supply adequate gas as a subsidized rate and ensure tax-free imports spare parts of gas generator. GOV should involve more power producer like Summit power in IPP.

\section{Expansion of renewable energy program}

Proper utilization of renewable energy is the up most choice for solving the power crisis in Bangladesh because it requires low cost and less risk.

\section{Development in solar energy program}

Solar energy program has glorious opportunity in Bangladesh. For enhancing solar energy program it is required to established at least 10 modern renewable energy research centre from where professional experts will come who can train others. For huge fund there may be built up public-private partnership program. Encourage IPP to expand their program. Champaign should be essential to aware the people to use solar panel and GOV should give subsidizes to import solar cell.

\section{Expansion of wind energy program}

Research organizations report shows that there is a prospect of wind Energy Program in Bangladesh. GOV should take initiative to produce electricity from wind power commercially. Private organizations like Grameen shakti and Rahim Afroz can participate to enhance the sector.

\section{Enhance biogas plant for power generation}

Biogas is produced by the decomposition of animal, plant and human wastage. Biogas plant could be established in the remote area where there is availability of that wastage. For implementing this, GOV should encourage IPP to set up biogas plant like Gazipur by giving technical and financial support. It should strongly be recommended that there is a bright future for biogas plant in the city corporation area like Dhaka, Chittagong, Khulna, Rajshahi, Sylhet and Borishal where thousand ton of wastage are wasting everyday which is polluting our environment. If those wastage can utilize properly then we can get power as well as we can save our environment from pollution.

\section{Implementation of Nuclear Power Plant}

There is a huge gap between supply and demand which is increasing day by day. Since maximum power plants are gas based and proven gas reserve is reducing and no new gas reserve has been discovered yet. This huge gap cannot be met by renewable energy. In that case nuclear power may be the alternative option for generating electricity. In the modern world, nuclear power has already been proved as cheap, reliable and safe. Now-a-days, the proven power rector design has achieved significant success in the forms of safety. As per recommendation of IAEA it could be set up three nuclear power plants of installed capacity $600 \mathrm{MW}$ in different places of the country such as Rooppur (Ishordi) already proposed in 1961, Hill tracks Chittagong and Sylhet that may cover $40 \%$ of the total demand.

\section{Reduction and protection of transmission loss}

The following steps should be taken for reduction and protection of transmission loss:

1. Copper losses could be minimized and conductivity increased in the transmission line by plating the line with silver. Since silver is better conductor than copper, most of the current will flow through the silver line.

2. Polyethylene may be used as dielectric which will consumed less power when its electron orbits are distorted.

3. The distance between generating station and distribution sub-station should be minimum to control the fluctuation of frequency to maintain the minimum loss in the line voltage. 
4. The protective components such as Circuit Breaker (CB), Relay, Fuse, Lightning Arrester and Isolator may be used to protect the transmission system loss.

5. To minimize distance and avoid risk underground transmission line should be implemented.

6. GOV should allocate sufficient fund for the development of transmission sector. Better opportunity should be created for skilled and qualified manpower.

7. Generation transmission mismatches should be solved properly.

8. Dependence of foreign countries for equipments, construction materials and spare parts should give up and try to depend on self equipments. In that case IPP may play the great role.

9. Corruption, dishonesty should remove by taking strong initiative by GOV and duty and responsibility of the employers should be done properly.

10. Introduction of low-loss amorphous core transformers.

11. Replacement with transformers of optimum capacity (resizing) and shortening of low-voltage line length by increasing the number of transformers.

\section{Ensured proper distribution}

Corruption and irresponsibility are the main obligations regarding power distribution. Load management means proper distribution and use of electricity. It could be suggested that for keeping load shedding at a minimum level and ensured proper distribution GOV should take the following initiatives:

1. Priority should be given to control misuse and corruption in power sector.

2. Government should take motivational programs to enhance awareness of the consumers during peak hours. Campaign should be essential to request the consumers through electronic and print media to be rational and economical in electricity use during peak hour by switching off, unnecessary loads like extra lighting ironing, pumps, air conditioners and welding machines etc.

2. Industries and large commercial customers like shopping malls should use their own captive generation and
GOV could transfer holiday in the markets and industrial belts.

3. Disconnect the illegal connection of electricity. In that case law enforcing agencies take the initiative. There should be punishment to the charged people.

4. Connect the modern error free meter and Implementation of pre-paid metering and meter sealing system will give additional facility.

5. Whole billing system should be under computer network and dues should be collected properly.

7. Latest technology should be implemented for the distribution of electricity. Insulated cable may used in the overhead transmission line. It is essential to modernize the distribution line, replace the old set up of the transformers and switch gear as early as possible. Lifetime and maintenance of all technical equipments should be ensured properly.

8. Employees of all levels must be responsible for their respective duties. As it is a technical work all employees should have the vast idea in this field. Administration should be ensured severe punishment for the dishonest employees and power station should be close to the load center.

9. Corporate culture may be implemented. Customer care and call centre may enhance the customer regarding power use and consumption.

10 Tariff should be included only for slum people. There should not be flat tariff in power sector.

11. Low income populations should be included in the field level work.

12. Cross-boarder interconnection and modified national generation plan may be implemented.

13. Load flow study may help the continuous evaluations of current performance of a power system and analyzing the effectiveness of alternative plans for system expansion to meet increased load demand.

14. Meter irregularity investigations and inspections must be supported by active enforcement of existing laws and procedures of energy theft. Administrative actions including disconnection, back billing, punitive damages 
and deposits on reconnection should be rigorously applied. In blatant or repeat cases it may be necessary to resort to legal actions, including criminal prosecution and civil actions in order to resolve the problem.

\section{Conclusion}

Electricity is required to produce goods and services for better quality of life. This is essential particularly in this age of globalization, information and communication technology. In Bangladesh power system is the interconnection between power generation, transmission and distribution. Due to interconnection, the power system becomes large and complex. Shortage of power is a serious problem and strong barrier for the development of our country. Misuse, system loss and corruption in power sector are the main issue regarding this crisis. Development of power sector indicates the increasing power generation, reducing transmission system loss and ensures proper distribution among the consumers. It could be possible to increase power generation by expanding renewable energy program and encouraging IPP to set up new power plant. Initiative should be taken to develop skilled manpower required for the power sector considering renewable energy sources. Priority should be given to control misuse and corruption in power sector. It could be possible to control the load demand by using compact fluorescent lamp (CFL), transferring holiday, proper load management and reducing system loss. By incorporating IPP and local GOV, central GOV may take the responsibility to increase the power generation and ensure its proper use in Bangladesh.

\section{References}

A publication of Spilling Energy System (2008) Gas Expansion Power Plants with Modular System Gas Expanders 27: 262-265.

Awal Kazi O. B. (2008) Electricity and Primary energy sources. Islamic University of Technology (IUG) Gazipur, Bangladesh. pp 53-70

Electrical and Electronic Engineering (EEE) Department, Islamic University of Technology (IUT), Gazipur, Bangladesh, December 2008, Lecture Handouts of the course on Electricity-the Most Preferred Form of Energy: Need, Accessibility, Affordability and Sustainability.

Power Division, Ministry of Power, Energy \& Mineral Resources, Government of the People's Republic of Bangladesh (MPEMR, 2009).

Khan M. K., June 2007 Vision of power sector 2020 Islamic University of Technology (IUT), Gazipur, Bangladesh, pp. 71-78.

Received : March, 15, 2009;

Accepted : June, 29, 2009 